\title{
Increased myofibrillar protein catabolism in Duchenne muscular dystrophy measured by 3-methylhistidine excretion in the urine
}

\author{
R. O. M C K E R A N, D. H A L L I D A Y, A N D P. P U R K I S S \\ From the Clinical Research Centre, Harrow, and University College Hospital, London
}

SU M MARY Myofibrillar protein catabolic rate was calculated in seven patients with Duchenne muscular dystrophy from the amount of 3-methylhistidine excreted in the urine, and found to be over three times that found in a control series when expressed as the percentage of myofibrillar protein catabolised per day. It is suggested that measurement of myofibrillar protein catabolic rate may add a useful parameter in the study of muscle disorders.

Duchenne muscular dystrophy is characterised pathologically by progressive muscle cell death with leakage of soluble enzymes into the plasma. Elevated levels of serum creatine phosphokinase (CPK, adenosine $5^{\prime}$ triphosphate-creatine phosphotransferase, EC 2.7.3.2) have been of great value in the diagnosis of the affected hemizygote, and in carrier detection. Recent observations (Ionasescu, 1975) have demonstrated abnormalities of protein synthesis in Duchenne muscular dystrophy, with high rates of synthesis of collagen, and low rates of non-collagen protein synthesis in the polyribosomes isolated from patients' muscles. A similar increased polyribosomal protein synthesis was found in the carriers for the X-linked gene (Ionasescu et al., 1971; lonasescu et al., 1973).

This study was undertaken to see whether calculation of myofibrillar protein catabolic rate from 3-methylhistidine excretion in the urine could be used as a simple method of detecting abnormalities in protein catabolism of muscle in the affected hemizygote, and thus of potential value in the diagnosis of the heterozygote, and possibly the affected hemizygote in utero.

\section{Patients and methods}

Seven institutionalised patients with classical sexlinked Duchenne muscular dystrophy were studied. None of the patients were ambulant at the time of

Address for correspondence and reprint requests: R. O. McKeran, Division of Inherited Metabolic Diseases, Clinical Research Centre, Watford Road, Harrow, Middlesex HA1 3UJ, England.

Accepted 4 May 1977 study and they were on a normal ward diet with no additional vitamin or drug therapy.

Urinary 3-methylhistidine was measured by means of a Technicon TSM amino acid analyser. The standard physiological fluid analysis cycle was curtailed so that only the basic amino acids were quantitated with L-canavanine as an internal standard. Urinary creatinine was measured by the method of Edwards and Whyte (1958).

Myofibrillar protein catabolic rate was calculated from the following formula, assuming the concentration of 3-methylhistidine in mixed proteins of human muscles is $1.76 \mu$ moles/g protein (Asatoor and Armstrong, 1967), and that myofibrillar protein constitutes $65 \%$ of total muscle protein.

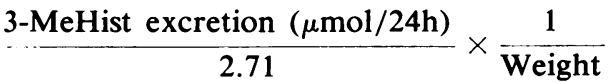

$$
\begin{aligned}
& \text { (kg) } \\
& \mathrm{g} \text { of myofibrillar protein } / \mathrm{kg} \text { body wt/day }
\end{aligned}
$$

The percentage turnover per day of myofibrillar protein was calculated from the following formula, assuming $1 \mathrm{~g}$ of creatinine excreted is equivalent to $20 \mathrm{~kg}$ of muscle, creatinine excretion is a measure of lean body mass in muscle diseases (Ryan et al., 1957), and protein constitutes $20 \%$ of muscle mass of which $65 \%$ is myofibrillar protein.

Myofibrillar protein catabolic rate (g/day)

Total muscle myofibrillar protein

Our results on these seven patients together with age- and sex-matched controls are summarised in 
the Table. Myofibrillar protein catabolic rate was found to be $0.72 \mathrm{~g} / \mathrm{kg}$ body wt/day (range $0.27-$ 1.26). Muscle mass was determined from creatinine excretion over 24 hours assuming $1.0 \mathrm{~g}$ of creatinine equal to $20 \mathrm{~kg}$ of muscle (Graystone, 1968) and myofibrillar protein to constitute $65 \%$ of total muscle protein. Myofibrillar protein catabolic rate was calculated as $7.3 \%$ /day of total muscle myofibrillar protein (range 2.92-14.05) which was over three times the normal value in healthy male volunteers (Young et al., 1975; McKeran et al., 1977). When allowance was made for the possibility of incomplete $24 \mathrm{~h}$ urine collection, by expressing the relationship of 3-methylhistidine to creatinine as their mole ratio, this similarly was found to be over three times the control value, confirming the threefold increase in myofibrillar protein catabolism in Duchenne muscular dystrophy.

\section{Discussion}

Recent estimates of myofibrillar protein catabolic rates in man have used measurements of 3-methylhistidine excretion in urine (Young et al., 1973; McKeran et al., 1977), since this amino acid is present in the actin of all muscles and the myosin of white muscle fibres, with a major proportion in skeletal muscle (Haverberg et al., 1975), it is quantitatively excreted in urine and is not reused for the purposes of protein synthesis (Young et al., 1972), or metabolised via oxidative pathways (Long et al., 1975). In a recent series of studies
(Halliday and McKeran, 1975; McKeran et al., 1977), the turnover of muscle protein, and the percentage contribution to whole body protein synthesis from muscle protein synthesis measured directly from serial muscle biopsies during continuous infusion of $\mathrm{L}-\left(\alpha^{-15} \mathrm{~N}\right)$ lysine, was compared with myofibrillar protein catabolism calculated from 3-methylhistidine excretion.

Previous reports of 3-methylhistidine excretion in Duchenne muscular dystrophy have shown increased amounts, but it has not been appreciated that 3-methylhistidine can be used as a marker of myofibrillar protein catabolic rate (Bank et al., 1971, Pennington, 1974). When myofibrillar protein catabolic rate was calculated as $\mathrm{g} / \mathrm{kg}$ of body weight/day in the present study, the results fell either within or below the normal range (Table). When expressed as the percentage turnover of total muscle myofibrillar protein, thus taking account of the reduced muscle mass, the true situation of increased muscle myofibrillar protein catabolism became apparent. The finding of decreased non-collagen protein synthetic rate in vitro (Ionasescu, 1975) coupled with our observations of increased myofibrillar protein catabolism are compatible and point to progressive muscle cell death with leakage of soluble enzymes into the plasma. A more fundamental abnormality of the assembly of contractile muscle protein and the regulation of its rate of catabolism is also possible.

Methods are now available which enable the carrier for Duchenne muscular dystrophy to be detected with a $70-80 \%$ certainty. Our reported

Table Clinical data on seven Duchenne muscular dystrophy patients, with their 3-methylhistidine excretion and calculated myofibrillar protein catabolic rate compared to control values

\begin{tabular}{|c|c|c|c|c|c|c|c|c|c|c|}
\hline $\begin{array}{l}\text { Patient } \\
\text { number }\end{array}$ & Age $(y r)$ & $\begin{array}{l}\text { Weight } \\
(k g)\end{array}$ & $\begin{array}{l}\text { Creatinine } \\
\text { excretion } \\
\text { (g/day) }\end{array}$ & $\begin{array}{l}\text { Muscle mass } \\
(\mathrm{kg})\end{array}$ & $\begin{array}{l}\text { Total muscle } \\
\text { myofibrillar } \\
\text { protein }(k g)\end{array}$ & $\begin{array}{l}\text { 3-MeHist } \\
\text { excretion } \\
\text { (mg/day) }\end{array}$ & $\begin{array}{l}\text { Mole ratio } \\
\text { 3-MeHist } \\
\text { creatinine }\end{array}$ & $\begin{array}{l}\text { Myofibri- } \\
\text { llar protein } \\
\text { catabolism } \\
\text { (g/day) }\end{array}$ & $\begin{array}{l}\text { Myofibri- } \\
\text { llar protein } \\
\text { catabolic } \\
\text { rate }(\mathrm{g} / \mathrm{kg} \\
\text { body wt/day) }\end{array}$ & $\begin{array}{l}\text { Turnover } \\
\text { myofibrillar } \\
\text { protein } \\
(\% / \text { day })\end{array}$ \\
\hline $\begin{array}{l}1 \\
2 \\
3 \\
4 \\
5 \\
6 \\
7\end{array}$ & $\begin{array}{l}17 \\
16 \\
18 \\
12 \\
15 \\
15 \\
19\end{array}$ & $\begin{array}{l}53.2 \\
60.5 \\
57.0 \\
65.5 \\
41.8 \\
74.8 \\
65.9\end{array}$ & $\begin{array}{l}0.363 \\
0.209 \\
0.234 \\
0.231 \\
0.146 \\
0.189 \\
0.227\end{array}$ & $\begin{array}{l}7.26 \\
4.18 \\
4.68 \\
4.62 \\
2.92 \\
3.78 \\
4.54\end{array}$ & $\begin{array}{l}0.94 \\
0.54 \\
0.61 \\
0.60 \\
0.38 \\
0.49 \\
0.59\end{array}$ & $\begin{array}{r}24.3 \\
16.9 \\
22.3 \\
8.0 \\
11.7 \\
15.4 \\
37.9\end{array}$ & $\begin{array}{l}0.045 \\
0.054 \\
0.064 \\
0.023 \\
0.054 \\
0.055 \\
0.111\end{array}$ & $\begin{array}{l}53.2 \\
37.0 \\
48.8 \\
17.5 \\
25.6 \\
33.7 \\
82.9\end{array}$ & $\begin{array}{l}1 \\
0.61 \\
0.86 \\
0.27 \\
0.61 \\
0.45 \\
1.26\end{array}$ & $\begin{array}{r}5.66 \\
6.85 \\
8.00 \\
2.92 \\
6.73 \\
6.88 \\
14.05\end{array}$ \\
\hline \multicolumn{3}{|l|}{$\begin{array}{l}\text { Mean and } \\
\text { range of } \\
\text { values }\end{array}$} & & & & $\begin{array}{l}19.5 \\
(8-37.9)\end{array}$ & $\begin{array}{l}0.058 \\
(0.023- \\
0.111)\end{array}$ & $\begin{array}{l}42.7 \\
(17.05- \\
82.9)\end{array}$ & $\begin{array}{l}0.72 \\
(0.27- \\
1.26)\end{array}$ & $\begin{array}{c}7.3 \\
(2.92- \\
14.05)\end{array}$ \\
\hline \multicolumn{2}{|c|}{$\begin{array}{l}\text { Control } \\
\text { mean and } \\
\text { range of } \\
\text { values } N=7\end{array}$} & & & & & $\begin{array}{l}39.6 \\
(32.8- \\
49.7)\end{array}$ & $\begin{array}{l}0.018 \\
(0.015 \\
0.020)\end{array}$ & $\begin{array}{l}86.7 \\
(71.8- \\
108.7)\end{array}$ & $\begin{array}{l}1.28 \\
(0.98- \\
1.54)\end{array}$ & $\begin{array}{l}2.21 \\
(1.87- \\
2.46)\end{array}$ \\
\hline
\end{tabular}


observations suggest that there should be an increased rate of catabolism of muscle myofibrillar protein in the heterozygote which could be detected by measurement of 3-methylhistidine excretion in the urine. However, for these expected smaller differences from the normal range, the subjects should be studied on a creatine free diet to exclude the dietary contribution to 3-methylhistidine excretion (McKeran et al., 1977). Since the affected male hemizygote in utero is thought to have an increased rate of muscle cell death this might be detected by increased levels of 3-methylhistidine in the amniotic fluid at 12 weeks. Finally, this method of measuring myofibrillar protein catabolism enables the response to new lines of treatment to be followed in a variety of muscle diseases characterised by progressive muscle cell death. These suggestions are currently under active study.

\section{References}

Asatoor, A. M., and Armstrong, M. D. (1967). 3methylhistidine, a component of actin. Biochemical and Biophysical Research Communications, 26, 168-174.

Bank, W. J., Rowland, L. P., and Ipsen, J. (1971). Amino acids of plasma and urine in diseases of muscle. Archives of Neurology (Chicago), 24, 176186.

Edwards, K. D. G., and Whyte, H. M. (1958). The measurement of creatinine in plasma and urine. Australian Journal of Experimental Biology and Medical Science. 36, 383-394.

Graystone, J. E. (1968). Creatinine excretion cluring growth. In Human Growth. p. 192. Edited by D. B. Cheek. Lea and Febiger: Philadelphia.

Halliday. D., and McKeran, R. O. (1975). Measurement of muscle protein synthetic rate and total body protein turnover in man by continuous intravenous infusion of L- $\left(\alpha^{-15} \mathrm{~N}\right)$ lysine. Clinical Science and Molecular Medicine, 49, 581-590.

Haverberg. L. N., Omstedt, P. T.. Munro, H. N., and Young, V. R. (1975). N-methylhistidine content of mixed proteins in various tissues. Biochimica et Biophysica Acta, 405, 67-71.
Ionasescu, V., Zellweger, H., and Conway, T. W. (1971). A new approach for carrier detection in Duchenne muscular dystrophy: protein synthesis of muscle polyribosomes in vitro. Neurology (Minneapolis), 21, 703-709.

Ionasescu, V., Zellweger, H., McCormick, W. F., and Conway, T. W. (1973). Comparison of ribosomal protein synthesis in Becker and Duchenne muscular dystrophies. Neurology (Minneapolis), 23, 245-253.

Ionasescu, V. (1975). Distinction between Duchenne and other muscular dystrophies by ribosomal protein synthesis. Journal of Medical Genetics, 12, 49-54.

Long, C. L., Haverberg, L. N., Kinney, J. M., Young, V. R., Munro, H. N., and Geiger, J. W. (1975). Metabolism of 3-methylhistidine in man. Metabolism, 24, 929-935.

McKeran, R. O., Halliday, D., and Purkiss, P. (1977). Comparison of the results obtained for muscle protein catabolic rate in man derived from the use of 3-methylhistidine excretion with those obtained for muscle protein synthetic rate from serial muscle biopsies during continuous intravenous infusion of L- $\left(\alpha^{-15} \mathrm{~N}\right)$ lysine. Clinical Science and Molecular Medicine. In press.

Pennington, R. J. T. (1974). Biochemical aspects of muscle disease. In Disorders of Voluntary Muscle. Pp. 488-516. Edited by J. N. Walton. Churchill Livingstone: Edinburgh and London.

Ryan, R. J., Williams, J. D.. Ansell, B. M., and Bernstein. L. M. (1957). The relationship of body composition to oxygen consumption and creatinine excretion in healthy and wasted men. Metabolism, 6, 365-377.

Young, V. R.. Alexis, S. D., Baliga, B. S., Munro, H. N., and Muecke, W. (1972). Metabolism of administered 3-methylhistidine. Lack of muscle t(RNA) charging and quantitative excretion as 3methylhistidine and its $\mathrm{N}$-acetyl derivative. Journal of Biological Chemistry, 247, 3592-3600.

Young, V. R., Haverberg. L. N., Bilmazes, C., and Munro, H. N. (1973). Potential use of 3-methylhistidine excretion as an index of progressive reduction in muscle protein catabolism during starvation. Metabolism, 22, 1429-1436.

Young, V. R., Munro, H. N., and Scrimshaw, N. S. (1975). Muscle and whole body protein metabolism in ageing with special reference to man. 5th Annual Meeting of the American Ageing Association, Chicago, Illinois. 